\title{
Evaluation of pregnancy rates of Bos indicus cows subjected to different synchronization ovulation protocols using injectable progesterone or an intravaginal device
}

\author{
Avaliação da taxa de prenhez de vacas Bos indicus submetidas à \\ sincronização da ovulação com diferentes protocolos a base de \\ progesterona injetável ou dispositivo intravaginal
}

\author{
Jefferson Tadeu Campos ${ }^{1}$; Fábio Morotti ${ }^{1}$; Camila Bortoliero Costa ${ }^{1}$; \\ Larissa Zamparone Bergamo ${ }^{1}$; Marcelo Marcondes Seneda ${ }^{2 *}$
}

\begin{abstract}
This study evaluated the pregnancy rate in Nelore cows (Bos indicus) that were subjected to fixedtime artificial insemination (FTAI) using different protocols consisting of injectable progesterone (P4) or an intravaginal device (impregnated with P4). Multiparous cows $72-84$ months in age, 30-45 days postpartum, were selected on the basis of the absence of a corpus luteum (CL) and follicles $<8 \mathrm{~mm}$ after transrectal palpation and ultrasound examinations. On a random day of the estrus cycle (D0), the selected animals $(n=135)$ were randomly assigned to one of three experimental groups $(n=45$ each). Group I (injectable P4/FTAI 36 hours) received $250 \mathrm{mg}$ of injectable P4 and $2 \mathrm{mg}$ EB on D0; on D7, they received $500 \mu \mathrm{g}$ of cloprostenol; on D8, $300 \mathrm{IU}$ of eCG and $1 \mathrm{mg}$ of EB were administered; and finally, FTAI was performed 36 hours after the application of EB. Group II (injectable P4/FTAI 48 hours) received the same protocol as Group I, except that the FTAI was performed 48 hours after ovulation induction. The animals of Group III (Control/CIDR) received a conventional protocol for FTAI using an intravaginal device (D0: P4 and $2 \mathrm{mg}$ EB; D8: device removal, $500 \mu \mathrm{g}$ cloprostenol, 300 IU eCG, $1 \mathrm{mg}$ EB; and FTAI performed 48 hours after removal of the device). The results showed that cows synchronized with the conventional protocol for FTAI (Control/CIDR) had a higher pregnancy rate $(60 \%, 27 / 45)$ than those synchronized with an injectable P4/FTAI 36 hours $(33.33 \% ; 15 / 45, \mathrm{P}=$ $0.010)$. However, the group receiving injectable P4 group/FTAI 48 hours had a similar pregnancy rate ( $48.9 \% ; 22 / 45 ; \mathrm{P}=0.290$ ) when compared to both the group receiving the conventional protocol and that receiving injectable $\mathrm{P} 4 / \mathrm{FTAI} 36$ hours $(\mathrm{P}=0.134)$. Although the injectable $\mathrm{P} 4$ may affect pregnancy rate with the FTAI performed in 36 hours, we found similar pregnancy rates from cows inseminated 48 hours after induction ovulation, considering injectable or intravaginal P4. Therefore, we suggest that injectable P4 represents an alternative source of progesterone for synchronization of cattle for FTAI. Key words: FTAI. Nelore. Injectable progesterone. Pregnancy rate.
\end{abstract}

\section{Resumo}

Este estudo avaliou a taxa de prenhez de vacas Nelore (Bos indicus) submetidas a diferentes protocolos de IATF a base de progesterona (P4) injetável ou dispositivo intravaginal impregnado com

\footnotetext{
${ }^{1}$ Discentes do Programa de Pós-Graduação em Ciência Animal, Universidade Estadual de Londrina, UEL, Londrina, PR, Brasil. E-mail: jcampos007@hotmail.com; fabiomorotti@hotmail.com; cbortoliero@gmail.com; larissabergamo1@hotmail.com

2 Prof., Dept ${ }^{\circ}$ de Clínicas Veterinárias, Laboratório de Reprodução Animal, Centro de Ciências Agrárias, UEL, Londrina, PR, Brasil. E-mail: mseneda@uel.br

* Author for correspondence
} 
P4. Vacas multíparas entre 72 e 84 meses de idade, com 30 a 45 dias pós-parto foram previamente selecionadas com base na ausência de corpo lúteo (CL) e folículos $<8 \mathrm{~mm}$ após palpação e exame ultrassonográfico transretal. Em um dia aleatório do ciclo estral (D0), os animais selecionados $(\mathrm{N}=$ 135) foram aleatoriamente distribuídos em um dos três grupos experimentais ( $\mathrm{n}=45$ / grupo). O grupo I (P4 injetável/IATF 36 horas) recebeu $250 \mathrm{mg}$ de P4 injetável e $2 \mathrm{mg} \mathrm{BE}$ no D0. No D7 aplicou-se 500 $\mu \mathrm{g}$ de Cloprostenol. No D8 $300 \mathrm{UI}$ de eCG e $1 \mathrm{mg}$ de BE foram administrados, sendo que a IATF foi realizada 36 horas após a aplicação do BE. O grupo II (P4 injetável/IATF 48 horas) recebeu o mesmo protocolo, exceto pela IATF que foi realizada 48 horas após indução da ovulação. Os animais do grupo III (Controle/CIDR) receberam um protocolo convencional de IATF com dispositivo intravaginal (D0 - P4 e 2 mg BE, D8 - remoção do dispositivo, $500 \mu \mathrm{g}$ Cloprostenol, 300 UI eCG, 1 mg BE e IATF realizada 48 horas após a remoção dos dispositivos). Os resultados foram analisados pelo teste do QuiQuadrado ( $\mathrm{p} \leq 0,05)$. No estudo, as vacas sincronizadas com protocolo convencional de IATF (Controle/ CIDR) apresentaram maior taxa de prenhez $(60 \% ; 27 / 45)$ do que aquelas submetidas à sincronização da ovulação com P4 injetável/IATF 36 horas (33,33\%; 15/45; p =0,01). Porém, o grupo P4 injetável/ IATF 48 horas demonstrou uma taxa de prenhez semelhante $(48,9 \% ; 22 / 45 ; \mathrm{p}=0,290)$ ao grupo com protocolo convencional e ao grupo de P4 Injetável/IATF 36 horas $(\mathrm{p}=0,134)$. Embora a P4 injetável demonstrou afetar a taxa de prenhez com à IATF realizada em 36 horas, as vacas inseminadas 48 horas após a indução da ovulação apresentaram taxas semelhantes às vacas que receberam dispositivo intravaginal. Portanto, sugere-se a P4 injetável uma fonte progesterônica alternativa para sincronização da ovulação em vacas.

Palavras-chave: IATF. Nelore. Progesterona injetável. Taxa de prenhez.

\section{Introduction}

Knowledge of the physiology of the estrus cycle in cattle has been crucial for developing specific pharmacological strategies to control the stages of follicular development (i.e., recruitment, selection, growth, maturation, and ovulation). These advances have greatly enhanced the efficiency of reproductive biotechnologies, especially for implementing the synchronization of ovulation protocols that are now well established for cattle (BARUSELLI et al., 2004; MOROTTI et al., 2013a).

Among the reproductive biotechnologies, artificial insemination (AI) is considered one of the most effective and low-cost strategies to achieve both genetic improvement and to increase the reproductive efficiency of herds (PEGORER et al., 2011). Strategies to increase the productive and reproductive performance in domesticated animals are necessary to ensure livestock farming remains profitable and sustainable. However, key characteristics of reproduction have low heritability; they, therefore, can be strongly influenced by environmental factors, nutrition, health, and management (BARUSELLI et al., 2004).
Following the development of the first protocols for fixed-time artificial insemination (FTAI), a wide variety of protocols have been developed specifically for each female category, namely to minimize costs, the animals' management, and to attain maximum reproductive efficiency. Among the many programs for FTAI, those using hormonal treatment based on progesterone ( $\mathrm{P} 4)$ coupled to estrogen have shown more satisfactory results in the synchronization of the growth follicular wave (SÁ FILHO et al., 2011; SALES et al., 2012). The action of P4 is widely known to inhibit estrus behavior and to block ovulation of the dominant follicle (LAMOND, 1964; GORDON, 1976; WHEATON; LAMB, 2007; QUEZADA-CASASOLA et al., 2014). In these protocols, P4 can be administered in different ways: via an ear implant, an intravaginal device, oral supplementation (BARUSELLI et al., 2004), or even as an injectable solution (MOROTTI et al., 2013a, b).

Health benefits, reduced handling costs, and greater convenience in parenteral application have been reported in a study with injectable P4 that was conducted in beef cattle (MOROTTI et al., 2013a). 
Despite these relative advantages, another study conducted by the same research group showed that cows synchronized with injectable P4 showed a lower pregnancy rate $(27.0 \%)$ than did those synchronized with an intravaginal device $(45.5$ \%) (MOROTTI et al., 2013b). Although a few studies have been conducted using injectable P4, more knowledge of this strategy's pharmacological adjustments, changes in the management of animal, and/or synchronization protocols could improve fertility in cows when synchronized this way. Thus, the aim of this study was to evaluate in Nelore cows their pregnancy rate after FTAI under different protocols using injectable P4 or a conventional intravaginal device.

\section{Materials and Methods}

The study was conducted on a farm located in Brazil, South America (latitude 23 24' 23" and longitude $57^{\circ} 26^{\prime} 4^{\prime \prime}$ ), during the breeding season of November 2013 to March 2014. The climate in this region is tropical, with an average daily temperature of $24^{\circ} \mathrm{C}$, and a rainy season from November to January.

During the experimental period, the cows were maintained by continuous grazing of Brachiaria brizantha and Brachiaria humindicula. They were given access to mineralized salt and water ad libitum.

\section{Animal selection}

A total of 135 Nelore cows (Bos indicus) were first selected based on the absence of a corpus luteum (CL) and a follicle $<8 \mathrm{~mm}$, as determined by palpation and ultrasound transrectal examinations (Aloka SSD-500, Tokyo, Japan). All selected cows were lactating (30-45 days postpartum); multiparous at 72-84 months old; and had a body condition score (BCS) between 2.5 and 3.5, on a scale of 0 to 5 (AYRES et al., 2009), and an average weight $( \pm$ SEM) of $410.3 \pm 47.5 \mathrm{~kg}$.

\section{Experimental design}

On a random day of the estrus cycle (D0) the selected cows $(n=135)$ were randomly assigned to one of three experimental groups $(n=45$ per group; Figure 1). The cows in Group I (P4 injectable/FTAI 36 hours) received an intramuscular (i.m.) dose of $250 \mathrm{mg}$ of injectable P4 (Progessincro, Laboratory Campos Ltda, Londrina, Brazil), in association with $2 \mathrm{mg}$ of estradiol benzoate (EB; Syntex ${ }^{\circledR}$, Syntex, Buenos Aires, Argentina). On D7, the cows received an i.m. dose of $500 \mu \mathrm{g}$ of cloprostenol (PGF2 $\alpha$; Cyclase ${ }^{\circledR}$ DL, Syntex, Buenos Aires, Argentina); 24 hours later (D8), they received an i.m. dose of 1 $\mathrm{mg}$ of EB in addition to $300 \mathrm{IU}$ of equine chorionic gonadotropin (eCG; Novormon ${ }^{\circledR}$, Syntex, Buenos Aires, Argentina). An FTAI was performed 36 hours after ovulation induction. For Group II (P4 injectable/FTAI 48 hours), the protocol for the synchronization of ovulation was identical that of Group 1, except the FTAI was performed 48 hours after ovulation induction. The cows in Group III (Control/CIDR) received a conventional protocol for FTAI using an intravaginal device that delivered $1.9 \mathrm{~g}$ of P4 (CIDR ${ }^{\circledR}$, Zoetis, São Paulo, Brazil) associated with an i.m. administered dose of $2 \mathrm{mg}$ of EB. The device was removed on $\mathrm{D} 8$, followed by an i.m. dose of $500 \mu \mathrm{g}$ of cloprostenol, $300 \mathrm{IU}$ of eCG, and $1 \mathrm{mg}$ of EC. An FTAI was performed 48 hours after device removal. The cows of the three groups were inseminated with frozen semen from the same bull, a single departure, and by the same inseminator.

\section{Statistical analyses}

The effects of the FTAI protocol on pregnancy rates of the three groups were analyzed by Chisquare tests. All of the data were analyzed using the Statistical Software Minitab, adopting a level of significance $5 \%$. 
Figure 1. Schematic representation of the three different synchronization protocols of ovulation that were tested Nelore cows (Bos indicus) using an injectable P4 solution (FTAI 36 or 48 hours after ovulation induction) or an intravaginal P4 device.

P4 INJECTABLE/FTAI 36H

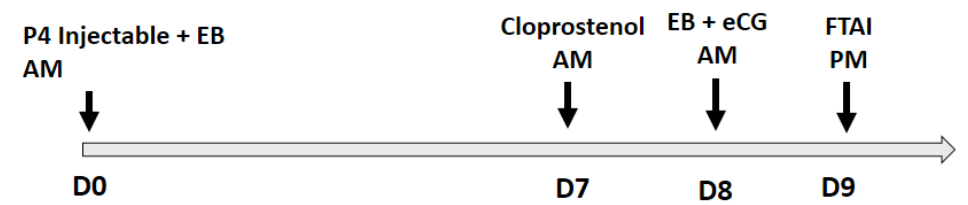

P4 INJECTABLE/FTAI 48H

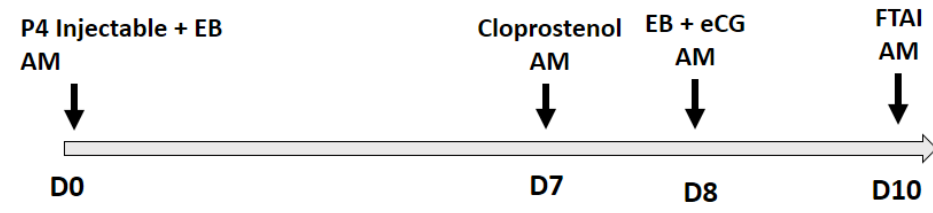

CONTROL/CIDR

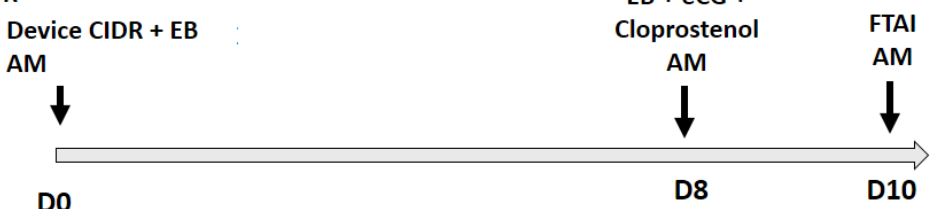

Note.

Group I: P4 injectable/FTAI 36 hours, 45 cows each received an i.m. dose of $250 \mathrm{mg}$ of injectable P4 and $2 \mathrm{mg}$ of EB on D0. On D7, an i.m. dose of $500 \mu \mathrm{g}$ of cloprostenol was administered, and 24 hours later (D8) $300 \mathrm{IU}$ of eCG and $1 \mathrm{mg}$ of EB was i.m. administered. The FTAI was performed 36 hours later (D9).

Group II: P4 injectable/FTAI 48 hours, 45 cows received the same protocol, except the FTAI was done 48 hours after ovulation induction (D10).

Group III: Control/CIDR, 45 cows each received an intravaginal device with $1.9 \mathrm{~g}$ of P4 and 2 mg of EB on D0. On D8, this device was removed, followed by i.m. administration of $500 \mu \mathrm{g}$ of cloprostenol, $300 \mathrm{IU}$ of eCG, and $1 \mathrm{mg}$ of EB. The cows were inseminated 48 hours after application of EB.

P4: Progesterone (Progessincro, Laboratory Campos Ltda, Londrina, Brazil or CIDR ${ }^{\circledR}$, Zoetis, São Paulo, Brasil). EB: Estradiol benzoate (Syntex ${ }^{\circledR}$, Syntex, Buenos Aires, Argentina). Cloprostenol (Cyclase ${ }^{\circledR}$ DL, Syntex, Buenos Aires, Argentina). eCG: Equine chorionic gonadotropin (Novormon ${ }^{\circledR}$, Syntex, Buenos Aires, Argentina).

\section{Results and Discussion}

This study is one of the few to report on the use of injectable P4 in FTAI protocols applied to beef cows. Our research group has pioneered the evaluation of injectable P4 on the parameters of ovarian follicular dynamics (follicular growth rate, diameter of the dominant and ovulatory follicle, ovulation rate and CL diameter) and pregnancy rates of Nelore cows submitted to a synchronization of ovulation (MOROTTI et al., 2013a, b).

While the present study confirmed results found earlier, it further revealed promising new information for using injectable P4 to control the bovine estrus cycle. This strategy may prove useful for the reproductive management of cattle, because injectable $\mathrm{P} 4$ offers management a way to reduce the cost and handling of cows, especially on farms with many females of reproductive age. These benefits are due to the greater control and convenience of a parenteral application, in addition to the hygienic and sanitary advantages of an injectable solution versus intravaginal devices that can lead to a higher incidence of reproductive tract disorders.

In this study, the cows synchronized with the conventional protocol FTAI (Control/CIDR) had a higher pregnancy rate $(60 \% ; 27 / 45)$ than those synchronized with P4 injectable/FTAI 36 hours (33.33\%; 15/45; $\mathrm{P}=0.01$; Figure 2). However, 
the group receiving injectable P4/FTAI 48 hours had a similar pregnancy rate $(48.9 \% ; 22 / 45)$ to those treated with either the conventional protocol $(\mathrm{P}=0.290)$ or $\mathrm{P} 4$ injectable/FTAI 36 hours $(\mathrm{P}=$
0.134). In this context, we highlight that injectable P4 presents another viable alternative source of P4 that could be used successfully in synchronization protocols for FTAI in cattle.

Figure 2. Pregnancy rates in Nelore cows (Bos indicus) that were submitted to a synchronization of ovulation (FTAI) using an injectable P4 solution/FTAI 36 hours, P4 injectable/FTAI 48 hours, or an intravaginal P4 device.

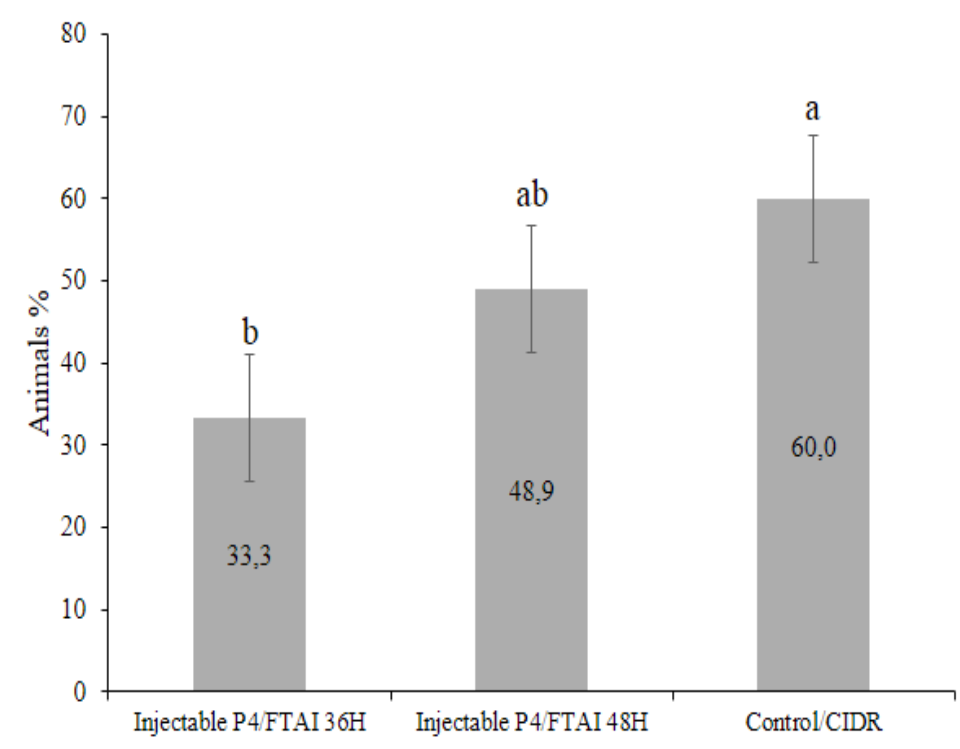

Note.

Different lower-case letters ( $a, b)$ indicate statistically different proportions of pregnant cows among the three treatment groups $(\mathrm{P}<0.05)$.

The control of estrous cycle using intravaginal devices has been widely used to maximize results of FTAI in cattle. Working with ovariectomized Nelore heifers, Maio et al. (2008) showed that the highest peak in plasma progesterone concentration $(8.00 \pm 0.58 \mathrm{ng} / \mathrm{mL})$ was achieved 24 hours after implantation of the intravaginal device. After this time interval, the concentration underwent a gradual reduction up to 216 hours, when it achieved the level of zero $\mathrm{ng} / \mathrm{mL}$. On the other hand, also using ovariectomized Nelore heifers, Silveira et al. (2012), observed the highest peak in plasma progesterone $(9.31 \pm 8.16 \mathrm{ng} / \mathrm{mL})$ in 6 hours after insertion of the intravaginal device. Although these devices remain on the animals for a period of 8 to 9 day, we consider a significant change in the progesterone plasma profile during this period of time. Considering the lack of information about injectable P4, so far we do not known its full metabolism period. We recently observed that the metabolism of injectable P4 seems to have some individual variation, but it is necessary more investigations about their action and metabolic degradation (MOROTTI et al., 2016) unpublished.

Morotti et al. (2013a) evaluated pregnancy rates in beef cows subjected to a synchronization protocol with injectable $\mathrm{P} 4$. The protocol of $350 \mathrm{mg}$ of P4 and $2 \mathrm{mg}$ of EB on D0, $500 \mu \mathrm{g}$ of cloprostenol and $300 \mathrm{UI}$ of eCG on D6, $1 \mathrm{mg}$ of EB on D7, and FTAI after 24 hours was used. Comparing with a conventional protocol with intravaginal P4 device, those authors found a higher pregnancy 
rate with the intravaginal device with $1 \mathrm{~g}$ of $\mathrm{P} 4$ $(45.2 \% ; 10 / 22)$ than for the group given $350 \mathrm{mg}$ of injectable P4 (18.1\%; 4/22; P = 0.050). A possible explanation for that may be the lower diameter of ovulatory follicles in animals that were submitted to injectable P4. But the number of animals was not too large and the comparison of both sources of progesterone will be improved when more works clarify the context.

We believe that a longer protocol may provide better results with injecatble progesterone. Our comprehension about that comes from the study of Morotti et al. (2013a) in which a short protocol - eight days - resulted in $18 \%$ of pregnancy rate, whereas here we showed rates from 33 to $48 \%$. The 10 day protocol seems to be appropriate to provide larger ovulatory follicles and better pregnancy rates.

Although these rates are below the rates found in this present study, the dosage and duration of treatments with injectable P4 are important differences between the two studies. It is thus possible that the smaller dose of injectable P4 (250 mg per animal) and the longer time for P4 to metabolize (FTAI performed in the D9 or D10) contributed to an improved pregnancy rate in the present study; moreover, the present study also included a larger sample size. Indeed, it is worth pointing out that a lower number of animals per group can limit a reliable assessment of the pregnancy rate.

Using $25 \mathrm{mg}$ of injectable P4 daily injections combined with $1 \mathrm{mg}$ of EB after 3 days the last application of P4 in Nelore, Ulberg and Lindley (1960) reported a lower pregnancy rate (38 \%; $16 / 42$ ) than that found in our present study. However, Silveira et al. (2012) reported a pregnancy rate of 53 $\%$ in Nelore cows using an intravaginal device, which corroborates our results for the Control/CIDR and P4 injectable/FTAI 48 hours groups. The pregnancy rate in our study was also similar to that reported by Schafer et al. (2007) that in lactating crossbred cows used $0.5 \mathrm{mg}$ melengestrol acetate (MGA) for 14 days versus CIDR intravaginal device both with
14 days of treatment. In this study, the MGA and CIDR device were similar (201/327, 61\%; 214/323, $66 \%$, respectively). Corroborates with our study Bader et al. (2005), also showed pregnancy rate of approximately $60 \%$ using melengestrol acetate orally for 14 days or 8 days for FTAI.

\section{Conclusion}

Using the P4 injectable to synchronization of Nelore cows, a lower fertility was observed with insemination performed 36 hours after ovulation induction. However, those animals inseminated with 48 hours showed pregnancy rates similar to animals synchronized with an intravaginal device. Therefore, we suggest that the injectable P4 represents an alternative progesterone source for synchronization in cattle.

\section{Acknowledgements}

We thank Dr. Renato Castanho Francisco for his support in this study, the staff of farm Santa Edwiges for letting us use their animals and installations, and the Graduate Program in Animal Science from the State University of Londrina, Londrina, Parana, Brazil. This research was funded in part by the Farm Santa Edwiges and Coordination for the Improvement of Higher Level or Education Personnel (CAPES).

\section{References}

AYRES, H.; FERREIRA, R. M.; TORRES-JÚNIOR, J. R. S.; DEMÉTRIO, C. G. B.; LIMA, C. G.; BARUSELLI, P. S. Validation of body condition score as a predictor of subcutaneous fat in Nelore (Bos indicus) cows. Livestock Science, Amsterdam, v. 123, n. 2-3, p. 175-179, 2009.

BADER, J. F.; KOJIMA, F. M.; SCHAFER, D. J.; STEGNER, J. E.; ELLERSIECK, M. R.; SMITH, M. F.; PATTERSON, D. J. A comparison of progestin-based protocols to synchronize ovulation and facilitate fixed time artificial insemination in postpartum beef cows. Journal of Animal Science, Champaign, v. 83, n. 1, p. 136-143, 2005. 
BARUSELLI, P. S.; REIS, E. L.; MARQUES, M. O.; NASSER, L. F.; BÓ, G. A. The use of hormonal treatments to improve reproductive performance of anestrous beef cattle in tropical climates. Animal Reproduction Science, Amsterdam, v. 82-83, p. 479486, 2004.

GORDON, I. Controlled breeding in cattle. Part 1: Hormone in the regulation of reproduction, oestrus, control and set time artificial insemination. Journal of Animal Breeding and Genetic, v. 44, n. 6, p. 265-275, 1976.

LAMOND, D. R. Synchronization of ovarian cycles in sheep and cattle. Journal of Animal Breeding and Genetics, v. 32, n. 3, p. 269-285, 1964.

MAIO, J. R. G.; SALES, J. N. S.; CREPALDI, G. A.; BARUSELLI, P. S.; CARVALHO, M. M.; SENEDA, M.

M. Perfil plasmático de progesterona e taxa de prenhez à IATF de fêmeas bovinas tratadas com Sincrogest ${ }^{\circledR}$ (Dispositivo Intravaginal de Progesterona). A Hora Veterinária, Porto Alegre, v. 28, n. 165, p. 41-44, sept./ oct. 2008.

MOROTTI, F.; CAMPOS, J. T.; OLIVEIRA, E. R.; SENEDA, M. M. Ovarian follicular dynamics of Nelore (Bos indicus) cows subjected to a fixed-time artificial insemination protocol with injectable progesterone. Semina: Ciências Agrárias, Londrina, v. 34, n. 6, p. 3865-3872, 2013b.

MOROTTI, F.; CAMPOS, J. T.; SENEDA, M. M. Fixed-time artificial insemination using injectable progesterone: ovarian follicular dynamics and pregnancy rates of Nelore cows (Bos indicus) with and without a corpus luteum. Semina: Ciências Agrárias, Londrina, v. 34, n. 6, p. 3873-3882, 2013a.

PEGORER, M. F.; ERENO, R. L.; SATRAPA, R. A.; PINHEIRO, V. G.; TRINCA, L. A.; BARROS, C. M. Neither plasma progesterone concentrations nor exogenous eCG affects rates of ovulation or pregnancy in fixed-time artificial insemination (FTAI) protocols for puberal Nellore heifers. Theriogenology, New York, v. 75, n. 1, p. 17-23, 2011.
QUEZADA-CASASOLA, A.; AVENDAÑO-REYES, L.; MACÍAS-CRUZ, U.; ALEJANDRO RAMÍREZGODÍNEZ, J.; CORREA-CALDERÓN, A. Estrus behavior, ovarian dynamics, and progesterone secretion in Criollo cattle during estrous cycles with two and three folicular waves. Tropical Animal Health and Production, Edinburgh, v. 46, n. 4, p. 675-684, 2014.

SÁ FILHO, M. F.; SANTOS, J. E.; FERREIRA, R. M.; SALES, J. N.; BARUSELLI, P. S. Importance of estrus on pregnancy per insemination in suckled Bos indicus cows submitted to estradiol/progesterone based timed insemination protocols. Theriogenology, New York, v. 76, n. 3, p. 455-63, 2011.

SALES, J. N. S.; CARVALHO, J. B. P.; CREPALDI, G. A.; CIPRIANO, R. S.; JACOMINI, J. O.; MAIO, J. R. G.; SOUZA, J. C.; NOGUEIRA, G. P.; BARUSELLI, P. S. Effects of two estradiol esters (benzoate and cypionate) on the induction of synchronized ovulations in Bos indicus cows submitted to a timed artificial insemination protocol. Theriogenology, New York, v. 78, n. 3, p. 510516, 2012.

SCHAFER, D. J.; BADER, J. F.; MEYER, J. P.; HADEN, J. K.; ELLERSIECK, M. R.; LUCY, M. C.; SMITH, M. F.; PATTERSON, D. J. Comparison of progestin-based protocols to synchronize estrus and ovulation before fixed-time artificial insemination in postpartum beef cows. Journal of Animal Science, Champaign, v. 85, n. 8 , p. 1940-1945, 2007.

SILVEIRA, E. C.; BORTOLLOTI, L. A.; MOROTTI, F.; SENEDA, M. M. Perfil plasmático de progesterona e taxa de prenhez de bovinos Nelore sincronizados com novo dispositivo intravaginal de progesterona (Biocowgest ${ }^{\circledR}$ ). Revista Acadêmica de Ciências Agrárias e Ambiental, Curitiba, v. 10, n. 1, p. 73-79, 2012.

ULBERG, L. C.; LINDLEY, C. E. Use of progesterone and estrogen in the control of reproductive activities in beef cattle. Journal of Animal Science, Champaign, v. 19, n. 4, p. 1132-1142, 1960.

WHEATON, J. E.; LAMB, G. C. Induction of cyclicity in postpartum anestrous beef cows using progesterone, $\mathrm{GnRH}$ and estradiol cypionate (ECP). Animal Reproduction Science, Amsterdam, v. 102, n. 3-4, p. 208216, 2007. 
